\title{
HUBUNGAN ANTARA PENYESUAIAN SOSIAL DENGAN KEPUTUSAN PEMBELIAN BARANG BERMEREK PADA REMAJA PUTRI DI SEMARANG
}

\author{
Alifia Nisaur Rahmah dan Erni Agustina Setiowati \\ Fakultas Psikologi Universitas Islam Sultan Agung \\ E-mail : erniagustina@unissula.ac.id
}

\begin{abstract}
Abstrak
Penelitian ini bertujuan menguji hubungan antara penyesuaian sosial dengan keputusan pembelian pada remaja putri di Semarang. Keputusan pembelian dilakukan seseorang untuk mencari solusi dan memutuskan membeli terhadap suatu barang, sedangkan penyesuaian sosial merupakan kemampuan seseorang dalam menjalin hubungan dengan orang lain, dengan memahami, menghormati dan menghargai lingkungan sekitar. Data diperoleh melalui skala keputusan pembelian barang bermerek yang terdiri dari 16 aitem dan skala penyesuaian sosial yang terdiri dari 39 aitem. Hipotesis yang diajukan yaitu terdapat hubungan yang positif antara penyesuaian sosial dengan keputusan pembelian barang bermerek pada siswi SMA Neegeri XX Semarang. Sampel penelitian sejumlah 65 siswi kelas XI di SMA Negeri XX Semarang yang dipilih melalui metode random sampling. Analisis data menggunakan korelasi produk moment yang dikembangkan oleh Karl Pearson. Hasil penelitian menunjukan bahwa ada hubungan positif yang signifikan antara keputusan pembelian dengan penyesuaian sosial berdasarkan hasil analisis statistik diperoleh nilai hasil nilai $r_{x y}$ sebesar 0,272 dan signifikansi $p=0,029(p<0,05)$.
\end{abstract}

Kata kunci : keputusan pembelian, penyesuaian sosial.

\section{RELATIONSHIP BETWEEN SOCIAL ADJUSTMENT AND CUSTOMER BUYING DECISION RELATED TO CONSUME LUXURY BRANDS OF TEENAGE GIRLS IN SEMARANG}

\begin{abstract}
This study aimed to examine the correlation between social adjustment and customer buying decision related to consume luxury brands of senior high school students in Semarang. The subject of this research is the students of eleventh grade in SMA XX Semarang. Buying decision is behavior related to search solution and decision to buy or not and social adjustment is a term which describe someone ability in develop a relationship with other to understand, respect and appreciate others. Sixty-five girl students involved in this study as samples. Data were collected by customer buying decision scale which consist of 16 items and social adjustment scale which consists of 39 items. Data were analyzed by product moment analysis. The result showed that there was a significant correlation between costumer buying decision and social adjustment based on statistic analysis with coefficient of correlation $r x y=0,272$ and $p=0,029(p<0,05)$.
\end{abstract}

Keyword : consumer buying decision, social adjustment. 


\section{Pendahuluan}

Media sosial merupakan suatu alat penunjang untuk memenuhi kebutuhan informasi di masa kini. Kebanyakan remaja yang menggunakan media sosial sebagai alat untuk mencari informasi tentang apapun dengan lebih mudah dan lebih cepat, serta media sosial juga membuat akrab dengan masyarakat luas bahkan hingga mancanegara. Media sosial dengan beragam bentuk aplikasi membuat remaja harus dapat menyesuaiakan diri, karena dengan remaja mengikuti perkembangan jaman mereka akan dapat menyesuaikan diri dengan lingkungan sekitarnya.

Masa remaja adalah masa peralihan seorang anak menjadi tumbuh dengan kematangan emosionalnya, terjadi perubahan pada perilakunya untuk mencari jati dirinya, dimana para remaja berusaha untuk menjadi bagian dalam lingkungan sekitarnya. Begitu pula ketika seorang remaja memutuskan untuk melakukan pembelian terhadap suatu barang. Remaja melihat barang pertama kali dari merek, karena merek merupakan trend yang semakin lama semakin berkembangan seiring perkembangan jaman, dan remaja selalu berusahan untuk mengikuti trend tersebut agar dapat diterima di lingkungan sekitarnya. Tuntutan remaja dalam penyesuaian sosial akan terpenuhi apabila remaja memiliki kemampuan menyikapi dan menyesuaikan diri terhadap situasi sosial yang sedang dihadapi. Penyesuaian diri itu sendiri dipengaruhi kelompok sebaya, perubahan sikap, dan masyarakat. Hal ini remaja diharapkan mampu bersosialisasi terhadap lingkungan.

Remaja selalu ingin menjadi bagian dari lingkungannya. Dalam usahanya ini, remaja berupaya untuk melakukan penyesuaian sosial yang baik sehingga cenderung akan mengikuti kebiasaan yang ada dalam lingkungannya. Hal ini sebagaimana studi pendahuluan yang dilakukan terhada empat remaja putri. Berikut ini pernyataan beberapa remaja tersebut :

"Aku suka barang bermerek karena lebih bagus kualitasnya daripada barang yang dipasaran walaupun harganya mahal, lebih pede juga kalau dipake kumpul bareng sama temen-temen" (ESV, 29 Mei 2017).

Hal yang senada juga disampaikan oleh SH dan PA yang mengungkapkan:

"kalau masalah barang-barang bermerek temen-temen aku yang sering update, nah aku tau infonya dari temen-temen kayak model terbaru, apalagi pas lagi banyak promo biasanya kita rame kesana abis pulang sekolah" (SH, 29 Mei 2017). Disaat yang bersamaan PA menyatakan "Misal lagi ada uang aku beli, tapi kalau lagi gak ada uang ya cuma lihat-lihat aja buat inceran kalau udah punya uang baru dibeli haha".

Sementara itu, remaja lainnya menyatakan :

"Dulunya aku tiap temenku pada ngomongin barang-barang bermerek, aku diem aja soalnya gak begitu paham, terus akhirnya aku mulai kepoin tu biar aku nyambung juga kalau pas temenku ngomongin, tak hemat uang sakuku buat beli barang bermerek yang aku pengen"(BZU, wawancara 29 Mei 2017).

Kotler dan Armstrong (1997) menjelaskan merek merupakan kesepakatan penjual untuk menyampaikan kegunaan dan jasa secara terperinci pada konsumen. Engel, Blackwell, dan Miniard (1995) berpendapat bahwa merek berpengaruh penting dalam perilaku pembelian dan menjadi pengganti kualitas produk. Seseorang seringkali melihat kualitas produk melalui pengakuan dari publik. Remaja dimasa sekarang ini, selalu mengikuti tren terbaru sehingga perusahaan berusaha mengejar perkembangan selera yang menjadi populer dikalangan remaja.

Kotler (2005) mengungkapkan keputusan seseorang dalam membeli suatu produk merupakan kumpulan dari beberapa pemikiran yang terdiri dari jenis produk, merek, bentuk produk, penjualan, pembayaran, jumlah produk dan keputusan waktu pembelian. Schiffman dan Kanuk (Saputra \& 
Samuel, 2013) berpendapat bahwa keputusan membeli merupakan salah satu pilihan atau lebih dari satu pilihan seseorang berdasarkan macam-macam pilihan produk yang ingin dimiliki.

Keputusan pembelian merupakan proses mencari dan memilih salah satu barang maupun jasa dari berbagai macam jasa atau produk untuk alternatif penyelesaian masalah dengan tindakan secara nyata. Keputusan pembelian merupakan suatu tindakan yang dilakukan sebagai solusi akhir dari pemilihan. Munandar (2001) menjelaskan bahwa konsumen dalam mengambil keputusan pembelian dipengaruhi oleh faktor diri sendiri dan jenis barang yang ditawarkan kepadanya, juga faktor lain dari lingkungannya seperti keluarga, kebudayaan, keluarga, status sosial, kelompok acuannya. Ma'ruf (2005) berpendapat bahwa pengambilan keputusan pembeli tidak hanya untuk mengambil solusi saat akan membeli, namun berlanjut hingga pembelian tersebut menjadi pengalaman bagi konsumen dan menjadi pertimbangan untuk memutuskan pembelian dimasa depan.

Terry (Djohan, 2015) mendefinisikan bahwa pengambilan keputusan merupakan cara alternatif untuk memilih dua atau lebih alternatif yang tersedia, sedangkan menurut Stoner (Djohan, 2015) mendefinifikan pengambilan keputusan sebagai suatu tindakan yang digunakan untuk memecahkan suatu masalah. Lebih lanjut Saiman (2009) menjelaskan pengambilan keputusan adalah pemilihan dua alternatif atau lebih pengambilan keputusan dilakukan karena perbedaan tujuan atau harapan dengan hasil yang diinginkan.

Proses pengambilan keputusan menurut Djohan (2015) dibagi menjadi empat, pertama fase intelijen yakni pencarian informasi melalui penjual atau distributor dan prestasi dari penjual terkait dengan barang yang akan dibeli. Selanjutnya fase desain, hal ini terjadi saat seseorang membuat kriteria yang diinginkan untuk mencegah masalah dan mempermudah dalam proses pembelian. Kemudian fase pemilihan yakni seseorang melakukan dengan pertimbangan, sehingga mendapat jaminan dan dapat dipertanggungjawabkan. Terakhir fase evaluasi dan tidak lanjut pasca pembelian. Pada fase keempat ini pertimbangan dilakukan dengan rentan waktu yang relatif lama, dengan pengenalan lebih dalam kualitas produk sebelum membeli. Sedangkan Saiman (2009) mengemukakan langkah-langkah pengambilan keputusan diantaranya, menentukan perlunya pengambilan keputusan, mengidentifikasi kriteria keputusan, mengalokasi pembobotan terhadap kriteria, mengembangkan alternatif, mengevaluasi alternatif, dan memilih alternatif terbaik.

Keputusan pembelian memiliki tiga aspek menurut Swastha, (1998), yang terdiri dari pertama aspek rasional yakni konsumen melakukan keputusan membeli dengan penuh pertimbangan dan sadar dalam melakukan pembelian guna mendapatkan apa yang diharapkan, selanjutnya aspek emosional yaitu individu melakukan keputusan membeli dengan dukungan naluri, perasaan dan pengalaman masa lalunya. Ketiga, aspek behavioral merupakan sebuah kondisi dimana individu mengambil keputusan untuk membeli dengan pertimbangan beberapa masukan dari lingkungan sekitarnya. Sedangkan Peter \& Olson (2002) menjelaskan bahwa aspek-aspek keputusan pembelian adalah (1) Respon reaktif, individu memutuskan membeli tanpa rencana dan secara umum tidak memiliki tujuan yang jelas; (2) little direct control, individu tidak memiliki kontrol terhadap tindakannya dalam memutuskan untuk membeli; (3) dapat dirasakan secara fisik, individu dapat merasakan respon fisik yang berupa kegairahan atau keinginan secara tiba-tiba saat melihat barang atau jasa yang akan dibeli; (4) respon to virtuality any type of stimulus, respon perilaku individu dapat memberikan respon terhadap pikiran-pikirannya sendiri; (5) respon afeksi adalah hasil belajar, respon afektifnya dapat melalui proses pengkondisian klasik. 
Hasil penelitian yang dilalukan oleh Wahyu (2014) diketahui bahwa penawaran dari produk seperti atribut produk, kualitas, fitur, tempat, desain, harga, promosi dan merek dapat menarik konsumen dalam mengambil keputusan pembelian. Sedangkan studi yang dilakukan oleh Sukesi \& Suyudanto (2010) menunjukkan bahwa pengaruh utama dalam keputusan pembelian adalah masalah pemasaran produk seperti harga, cara pembayaran, dan cara pengiriman, sehingga ukuran pembelian bertujuan untuk mempengaruhi orang lain.

Perilaku pengambilan keputusan membeli dipengaruhi dengan adanya faktor emosi dari pada rasio, sehingga mengakibatkan membeli produk tanpa melakukan pertimbangan pengambil keputusan membeli barang lebih mengutamakan status sosial, penyesuaian sosial, dan trend. Pilihan emosional biasanya didasarkan atas kurangnya penyesuaian sosial dilingkungan teman sebayanya dan keinginan bersaing untuk diakui penampilan diri mereka. Barang yang menonjol secara visual adalah produk yang mencolok diperhatikan seperti produk mewah, memiliki logo yang terkenal, sedangkan produk yang menonjol adalah barang menarik dan bisa digambarkan lebih mudah atau memiliki karakteristik khas dibandingkan produk lain.

Hasan (2008), menjelaskan ada lima faktor yang berpengaruh dalam pengambilan keputusan pembelian, yakni pertama, pengambilan inisiatif (intitator) merupakan konsumen yang sadar terhadap kebutuhan yang belum terpenuhi dan berusaha mengusulkan untuk membeli. Kedua, orang yang mempengaruhi (influencer) merupakan orang yang sering berperan sebagai pemberi pengaruh yang karena pandangan nasihat atau pendapatannya mempengaruhi keputusan pembelian. Selanjutnya, pembuat keputusan (decider) merupakan orang yang mengambil keputusan untuk menentukan barang yang akan dibeli, bagaimana cara membeli, dan dimana barang dibeli. Kemudian pembeli (buyer) merupakan konsumen yang melakukan pembelian sebenarnya, dan terakhir pemakai (user) merupakan orang yang menggunakan maupun memakai barang yang dibeli. Saiman (2009) menjelaskan bahwa factor-faktor yang berperan terhadap pengambilan keputusan pembelian diantaranya (1) nilai-nilai yang merupakan pedoman konsumen dalam menghadapi situasi dimana harus dilakukannya suatu pemilihan barang atau jasa, (2) kepribadian yang meliputi beberapa aspek diantaranya kepercayaan, sikap, dan kebutuhan konsumen itu sendiri, (3) kecenderungan mengambil resiko pada diri konsumen, artinya ada yang memiliki keberanian dalam mengambil resiko, ada yang seimbang, dan ada pula yang kurang berani dalam mengambil resiko atau penuh pertimbangan, (4) disonasi kognitif yakni konsumen mengalami kecemasan pada saat pengambilan keputusan terhadap akibat dari keputusan yang diambilnya.

Kotler dan Keller (2012) mengungkapkan terdapat 4 faktor yang mempengaruhi keputusan pembelian yakni budaya, sosial, pribadi, dan psikologis. Faktor budaya, dalam hal ini berperan penting dalam menentukan keinginan dan perilaku yang paling dasar dalam mendorong seseorang untuk membeli. Sedangkan faktor sosial berpengaruh karena didalamnya terdapat kelompok acuan yang merupakan kelompok yang mempengaruhi tindakan maupun perilaku seseorang dalam mengambil keputusan, baik secara langsung maupun tidak langsung. Selain itu dalam konteks social juga ada keluarga. Terdapat dua bagian dalam keluarga, yaitu : keluarga orientas terdiri dari ibu, ayah dan saudara kandung dan keluarga prokreasi terdiri atas pasangan serta jumlah anak yang dimiliki. Disamping kelompok acuan dan keluarga, dalam bahasan social juga terdapat peran dan status yakni yang menjadi penyebab sosial yang berpengaruh pada tindakan membeli, semakin tinggi peran seseorang dalam masyarakat maka semakin tinggi pula dampak perilaku pembeliannya. Faktor pribadi dalam konteks keputusan pembelian adalah terkait dengan karakteristik pribadi diantaranya

97 
usia dan tahap siklus hidup, kepribadian, pekerjaan, ekonomi, gaya hidup. Usia dan siklus hidup keluarga akan berpengaruh terhadap pembelian produk dan jasa yang berbeda-beda. Begitu pula dengan jenis pekerjaan yang digeluti dan lingkungan ekonomi memiliki dampak terhadap tingkat konsumsi konsumen. Selain itu, pola hidup konsumen dapat dilihat pada kegiatan, ketertarikan serta opininya melalui kelas sosial dan pekerjaannya serta konsumen dengan karakter tertentu yang berbeda mempengaruhi tingkat pembelian. Faktor psikologis yang ditengarai berperan dalam keputusan pembelian diantaranya motivasi konsumen, persepsi terhadap situasi tertentu sehingga berpengaruh terhadap tindakan yang diambil, adanya pembelajaran yang meliputi perubahan perilaku seseorang yang timbul dari pengalaman, dan yang terakhir adalah keyakinan dan sikap. Seseorang memiliki keyakinan dan sikap melalui tindakan dan pengalaman. Keyakinan konsumen terkait dengan merek produk akan mempengaruhi keputusan pembeliannya.

Kotler (2005) mengungkapkan bahwa keputusan pembelian dilihat dari faktor psikologis dan faktor pribadi individu dipengaruhi oleh kekuatan internal maupun eksternal seperti lingkungan, teman sebaya, keluarga, maupun dari dalam diri individu sebagai dorongan untuk menyesuaikan diri dilingkungan sekitar.

Salah satu faktor yang berkontribusi terhadap keputusan membeli yakni penyesuaian social seseorang di lingkungannya. Penyesuaian sosial merupakan kemampuan seseorang untuk menjalin hubungan baik dengan orang lain dengan cara menghargai pendapat orang lain, memahami dan menghormati orang-orang yang berada di sekitarnya. Hurlock (2002) mengemukakan bahwa penyesuaian sosial sebagai kesuksesan seseorang untuk menyesuaikan diri terhadap orang lain pada umumnya dan terhadap kelompok pada khususnya. Dengan kata lain, penyesuaian sosial adalah cara adaptasi seseorang terhadap orang-orang disekitarnya, sehingga mampu bersosialisasi dengan baik terhadap orang lain yang dikenali maupun tidak dikenal. Seseorang yang memiliki penyesuaian sosial yang baik cenderung memiliki banyak teman. Berdasarkan kamus psikologi Chaplin (2008) berpendapat bahwa penyesuaian sosial sebagai berhubungan yang terjalin erat atau memiliki kedekatan dengan lingkungan, dengan mengamati tindakan yang diperlukan dan berusaha mengganti kebiasaan yang ada sehingga dapat diterima masyarakat. Kaitannya dengan penyesuaian sosial, Sears dkk. (1992) mengungkapkan remaja dituntut untuk dapat membina dan menyesuaikan diri dengan relasi-relasi yang baru dalam beragam situasi, sesuai dengan peran yang dibawakannya pada saat itu.

Penyesuaian sosial dapat menjadi pemicu seseorang untuk melakukan suatu tindakan, dimana individu mampu melakukan penyesuaikan diri terhadap teman sebaya, orang dewasa maupun kelompok yang menjadi figur panutan individu dalam berperilaku, berpenampilan nyata, maupun bersikap. Terdapat beberapa aspek dalam penyesuaian sosial menurut Schneiders (1964) antara lain (1) recognition adalah menghormati dan menerima hak-hak orang lain. Seseorang yang mampu menghargai hak orang lain serta menghargai pendapat orang lain akan terhindar dari permasalahan dilingkungan sosial; (2) participation adalah melibatkan diri dalam berelasi. Individu memiliki kemampuan dalam membangun kepercayaan orang lain terhadap dirinya, menjalin kekerabatan dan persahabatan yang baik serta berperan aktif dalam kegiatan masyarakat akan menjadikannya memiliki penyesuaian yang sehat; (3) social approval adalah minat dan simpati terhadap kesejahteraan orang lain. Individu memiliki kepedulian terhadap kesulitan orang lain dengan membantu meringankan bebannya; (4) altruisme adalah memiliki sifat rendah hati dan tidak egois. Individu memiliki rasa kemanusiaan, rendah diri dan kejujuran terhadap orang-orang disekelilingnya 
sifat ini akan menjadikan mentalnya kestabilan mental sehingga mampu melakukan penyesuaian yang baik; (5) conformity adalah menghormati dan mentaati nilai-nilai dan integritas hukum, kebudayaan serta kebiasaan. Individu menghormati dan tidak melanggar peraturan-peraturan dan tata tertib masyarakat, maka individu akan diterima oleh masyarakat dengan baik.

Menurut Tambunan (2001) pelaku pembelian secara konsumtif mayoritas pada remaja, sehingga remaja cenderung bertindak dengan pertumbuhan yang belum semestinya seperti orang dewasa.

Berdasarkan fenomena tersebut di atas, diduga remaja yang memiliki masalah penyesuaian sosial, sehingga mereka melakukan usaha untuk menyesuaikan diri di lingkungan sekitarnya dengan cara mengikuti perkembangan produk fashion yang menjadi trend dan bermerek. Untuk itu penulis mengajukan hipotesis ada hubungan positif antara penyesuaian sosial dan keputusan pembelian barang bermerek pada remaja putri di Semarang.

\section{Metode}

Metode kuantitatif korelasional dipilih dalam menguji hipotesis dalam penelitian ini yang memiliki dua variabel yaitu penyesuaian sosial yang merupakan variabel independen dan variabel dependen yakni keputusan pembelian. Populasi dalam penelitian ini adalah siswi SMA Negeri XX di Semarang yang diambil dari kelas XI dimana terdapat 14 kelas dan terdapat 293 siswi. Sampel yang dilibatkan dalam penelitian ini sebanyak 65 siswi yang dipilih melalui teknik random sampling.

Pengambilan data menggunakan skala keputusan pembelian yang disusun berdasarkan aspek rasional, aspek behavioral, dan aspek emosional. Aspek rasional yaitu konsumen melakukan keputusan membeli dengan penuh pertimbangan dan sadar dalam melakukan pembelian guna mendapatkan apa yang diharapkan. Aspek emosional berkaitan dengan konsumen melakukan keputusan untuk membeli dengan dorongan naluri, perasaan dan pengalaman sebelumnya. Sedangkan aspek behavioral yakni konsumen mengambil keputusan untuk membeli dengan pertimbangan beberapa pendapat dan tekanan dari lingkungan eksternal.

Skala pengukuran ini terdiri dari 16 aitem dengan indeks daya beda aitem bergerak antara 0,38 sampai 0,659 dan reliabilitas Alpha sebesar 0,769. Berikut contoh aitem unfavorable yang ada pada skala keputusan pembelian "Keluarga dan teman tidak mempengaruhi saya untuk membeli barang". Semakin tinggi skor yang diperoleh seseorang dalam skala ini maka semakin tinggi individu tersebut dalam melakukan keputusan pembelian.

Cara pengambilan data berikutnya melalui skala penyesuaian sosial yang disusun berdasarkan indiikator-indikatornya yaitu recognition, participation, sosial approval, altruisme, dan conformity.

Skala penyesuaian sosial terdiri dari 39 aitem dan memiliki daya beda aitem berkisar antara 0,25 sampai 0,669 serta reliabilitas Alpha sebesar 0,921. Skala pengukuran terdiri dari empat pilihan respon atau pilihan jawaban, untuk aitem favorable yaitu SS (Sangat Sesuai) diberi skor 4, S (Sesuai) memiliki skor 3, TS (Tidak Sesuai) diskor 2, dan STS (Sangat Tidak Sesuai) diberi skor 1, untuk aitem unfavorable berlaku sebaliknya. Berikut contoh aitem favorable pada skala ini "Saya menghabiskan waktu dengan teman-teman saat ada waktu kosong". Semakin tinggi skor yang diperoleh seseorang dalam skala ini maka semakin tinggi individu tersebut melakukan penyesuaian sosial 
Hubungan Antara Penyesuaian Sosial Dengan Keputusan Pembelian Barang Bermerek Pada Remaja

Analisis data dalam penelitian ini menggunakan teknik analisis product moment yang dikembangkan oleh Karl Pearson. Analisis ini dikerjakan dengan bantuan program SPSS (Statistic Packeage for Social Science) versi 16 for windows.

\section{Hasil dan pembahasan}

Sebelum melakukan uji hipotesis data dalam penelitian ini dilakukan asumsi berupa uji normalitas dan uji linearitas data. Hasil uji normalitas data dengan menggunakan teknik One Sample Kolmogorov Smirnov Z diketahui data variabel keputusan pembelian diperoleh $K-S Z=0,712$ dengan $p=0,690(p$ > $0,05)$, sedangkan data variabel penyesuaian sosial diperoleh K-S $Z=0,802$ dengan $p=0,541(p>$ $0,05)$. Hal ini berarti bahwa sebaran data variable keputusan pembelian dan variable penyesuaian sosial memiliki distribusi normal. Hasil uji linearitas antara data variabel keputusan pembelian dan data variabel penyesuaian sosial diperoleh $F_{\text {linear }}$ sebesar 5,137 dengan taraf signifikansi $p=0,027$ ( $p<$ $0,05)$. Hal ini berarti bahwa data antara variabel keputusan pembelian dan variabel penyesuaian sosial terdapat hubungan yang linear. Berikut hasil analisis statistik deskriptif data penelitian.

Tabel 1. Deskripsi Statistik Variabel Penelitian

\begin{tabular}{lcc}
\hline & Keputusan pembelian & Penyesuaian sosial \\
\hline Skor Minimal & 41 & 93 \\
Skor Maksimal & 64 & 156 \\
Rerata & 51,553 & 125,738 \\
Deviasi Standar & 5,500 & 13,423 \\
\hline
\end{tabular}

Berdasarkan hasil analisis terhadap hipotesis diketahui bahwa ada hubungan yang signifikan antara keputusan pembelian dan penyesuaian sosial, yaitu diketahui koefisien korelasi $r_{x y}$ sebesar 0,272 dan signifikansi $p=0,029(p<0,05)$. Hasil pengujian diatas menunjukkan bahwa hipotesis yang diajukan penulis diterima yaitu ada hubungan yang positif antara keputusan pembelian dan penyesuaian sosial pada siswa SMA Negeri XX Semarang. Sedangkan berdasarkan kategorisasi data, diketahui bahwa sampel berada pada kategori tinggi baik pada hasil pengukuran variabel keputusan pembelian maupun variabel penyesuaian social.

Remaja, dalam hal ini siswi SMA yang menjadi sampel dalam penelitian dalam melalukan keputusan pembelian terhadap merek tertentu berhubungan dengan kemauannya untuk melakukan penyesuaian diri di lingkungan sosialnya, baik lingkungan keluarga maupun teman sebayanya. Tuntutan remaja dalam penyesuaian sosial akan terpenuhi salah satunya apabila remaja memiliki kemampuan menyikapi dan menyesuaikan diri terhadap situasi sosial yang sedang dihadapi. Kebutuhan remaja untuk diterima dan menjadi sama dengan orang lain yang sebaya, hal ini menyebabkan remaja berusaha untuk mengikuti berbagai atribut yang sedang menjadi trend masa kini. Mereka ingin menunjukkan diri bahwa mereka juga dapat mengikuti trend yang sedang beredar di media sosial, internet. Kecenderungan atau trend yang selalu berubah dan berkembang dapat membuat remaja tidak mudah merasa puas dengan apa yang dimilikinya dan berusaha mengejar trend terbarunya. Hal ini sejalan dengan penelitian yang dilakukan oleh Aisyah (2016) yang menjelaskan bahwa pengaruh kelompok secara signifikan mempengaruhi keputusan pembelian seseorang. Pengaruh sutau kelompok atau organisasi yang ada di sekitar konsumen menjadi pertimbangan konsumen untuk melakukan keputusan pembelian terhadap suatu barang. 
Martaniah (1982) berpendapat bahwa tingginya peran teman sebaya pada masa remaja karena remaja menyadari adanya tekanan-tekanan sosial dan perlunya mengadakan relasi sosial, sehingga harus lebih banyak melakukan aktivitas dengan sebayanya. Lebih lanjut, penerimaan teman sebaya merupakan isu penting bagi remaja, hal ini disebabkan pada periode ini terjadi perubahan orientasi hubungan individu dari keluarga ke lingkungan yang lebih luas sehingga hubungan remaja dan orangtua menjadi longgar. Hubungan yang lebih luas ini didalamnya tercakup masalah pertemanan dengan sebaya.

Agar lebih mudah diterima di lingkungannya seringkali remaja mengubah penampilannya menjadi lebih menarik dengan mengikuti trend yang sesuai dengan teman-temannya. Sehingga banyak upaya yang akan dilakukan untuk menyesuaikan dirinya dengan lingkungannya agar selaras. Sari (2013) menjelaskan menjelaskan bahwa keputusan pembelian juga dipengaruhi oleh karakteristik pribadi seperti usia pembeli, keadaan ekonomi, gaya hidup dan kepribadian pembeli. Selain itu juga disebutkan bahwa faktor pribadi tersebut memiliki pengaruh positif secara signifikan terhadap keputusan pembelian. Hal ini juga sesuai dengan penelitian yang dilakukan oleh Setianingsih, Uyun, \& Yuwono (2006) yang menjelaskan bahwa semakin tinggi tingkat penyesuaian sosial remaja maka akan semakin rendah masalah yang dihadapi dan apabila penyesuaian sosial remaja rendah maka akan semakin tinggi masalah yang dihadapi.

Seperti yang dijelaskan oleh Munandar (2001) bahwa pengambilan keputusan konsumen untuk membeli suatu barang dipengaruhi oleh beberapa faktor seperti keluarga, kebudayaan, status sosial dan kelompok acuannya. Menurut wawancara pendahuluan yang dilakukan oleh peneliti menunjukkan bahwa keputusan pembelian siswa SMA Negeri XX Semarang terhadap suatu barang bermerek tergantung dari pengalaman teman sekelompok yang sudah lebih dulu menggunakan barang bermerek tersebut. Hal tersebut sesuai dengan teori Kotler dan Keller (2012) yang menjelaskan bahwa salah sumber pencarian informasi terhadap suatu barang berasal dari pengalaman melalui pembelajaran terhadap produk. Wibowo (2014) menjelaskan dalam hasil penelitiannya bahwa faktor sosial mempunyai pengaruh yang signifikan terhadap keputusan pembelian. Hal ini karena faktor sosial merupakan kesatuan sosial yang menjadi tempat individu berinteraksi satu sama lain, oleh karena itu ketika konsumen memberikan referensi suatu barang kepada teman, maka akan cenderung direspon dengan cepat. Kondisi ini juga ditemui penulis sebagaimana penuturan siswa saat wawancara mengatakan bahwa dirinya melakukan keputusan pembelian terhadap barang bermerek dan ketika tidak memiliki uang saku maka akan memanfaatkan diskon atau promosi.

Keputusan pembelian barang bermerek, dalam hal ini pada remaja yang bersekolah di SMA tentunya terkait dengan konsumsi barang yang erat kaitannya dengan kehidupan remaja dimasa dan tempat atau lokasi tertentu. Sehingga batasan barang bermerek yang dimaksud dalam penelitian ini penentuannya kurang tegas, oleh karena itu perlu kajian yang lebih luas dan mendalam mengenai keputusan pembelian yang terkait dengan merek tertentu atau jenis barang tertentu dan penyesuaian sosial remaja. Disamping itu, penyesuaian sosial yang dikaji dalam penelitian ini tidak spesifik terhadap teman sebaya, namun masih mempertimbangkan penyesuaian remaja dalam keluarganya. 
Hubungan Antara Penyesuaian Sosial Dengan Keputusan Pembelian Barang Bermerek Pada Remaja Putri di Semarang Proyeksi Vol. 14 (1) 2019, 94-103

\section{Kesimpulan}

Berdasarkan hasil penelitian maka dapat disimpulkan bahwa terdapat korelasi positif antara penyesuaian sosial dan keputusan pembelian, diperoleh memiliki $r_{x y}=0,272$ dan taraf signifikansi $p=$ $0,029(p<0,005)$. Dengan demikian, hipotesis yang diajukan peneliti diterima yaitu semakin tinggi penyesuaian sosial maka akan semakin tinggi keputusan pembelian dan semakin rendah penyesuaian sosial dengan teman-teman satu kelompoknya maka akan semakin rendah keputusan pembelian remaja putri terhadap barang bermerek

\section{Daftar Pustaka}

Aisyah, W. (2016). “Analisis Faktor Pengambilan Keputusan Pembelian Buku Di Toko Buku Gramedia Botani Square Bogor". Skripsi. Institut Pertanian Bogor.

Chaplin, J. P. (2008). Kamus Lengkap Psikologi (terjemahan). Jakarta: PT. Raja Grafindo Persada.

Djohan, A. J. (2015). Manajemen \& Strategi Pembelian. Malang: Media Nusa Creative.

Engel, J. F., Blackwell, R. D., \& Miniard, P. W., (1995). Consumer Behavior. Eight edition. Orlando: The Dryden Press.

Hasan, A. (2008). Marketing. Yogyakarta: Media Utama.

Hurlock, E. B. (2002). Psikolo, gi Perkembangan. Edisi Kelima. Jakarta: Erlangga.

Kotler, P., \& Armstrong, G. (1997). Dasar-Dasar Pemasaran (terjemahan). Edisi 7. Jilid 1. Jakarta: Prenhallindo.

Kotler, P. (2011). Manajemen Pemasaran (terjemahan). Jilid 2. Jakarta: Bumi Aksara.

Kotler, P., Keller.,\& Kevin, L. (2012). Marketing Management $14^{\text {th }}$ Edition. New Jersey: Pearson Education, Inc.

Ma'ruf, H. 2005. Pemasaran Ritel. Jakarta. PT. Gramedia Pustaka Utama. Jakarta.

Martaniah, S. M. 1982. Motif Sosial Remaja Suku Jawa dan Keturunan Cina di Beberapa SMA Yogyakarta. Suatu Studi Perbandingan. Disertasi. Tidak Diterbitkan. Yogyakarta: Fakultas Psikologi Universitas Gadjah Mada

Munandar, A. S. (2001). Psikologi Industri dan Organisasi. Jakarta: Penerbit Universitas Indonesia.

Peter, J. P. \& Olson, J. C. (2002). Perilaku Konsumen dan Strategi Pemasaran (terjemahan). Jakarta: Erlangga.

Saputra, R, \& Samuel, H. .S.E.,M.S (2013). Analisa Pengaruh Motivasi, Persepsi, Sikap Konsumen Terhadap Keputusan Pembelian Mobil Daihatsu Xenia di Sidoarjo. Jurnal Manajemen Pemasaran, Vol. 1(1), Hal. 1-12.

Saiman, L. (2009). Kewirausahaan. Jakarta: Penerbit Salemba Empat.

Sari, Ade, I. (2013). Faktor-Faktor Yang Mempengaruhi Perilaku Konsumen Dalam Keputusan Pembelian Ponsel Blackberry Pada Mahasiswa STIE Harapan Medan. Jurnal E-Maksi Harapan. STIE Harapan Medan. 
Schiffman \& Kanuk. (2007). Perilaku Konsumen (terjemahan). Edisi Kedua. Jakarta: PT. Indeks Gramedia.

Schneiders, A. (1964). Personal Adjustment and Mental Health. New York, Hoolt, Rinehart and Winston.

Sears, D. O, Freedman, J. L. \& Peplau, L. A. 1992. Psikologi Sosial Jilid I. Terjemahan: Michael, A. dan Savitri, S. Jakarta: Erlangga.

Setianingsih, E., Uyun, Z., \& Yuwono, S. (2006). Hubungan antara penyesuaian sosial dan kemampuan menyelesaikan masalah dengan kecenderungan perilaku delinkuen pada remaja. Jurnal psikologi, 3 (1), 29-35.

Sukesi, \& Suyudanto, A. A. (2010). Analisis Pengaruh Kekuasaan dan Kemampuan Individu Anggota Tim. Jurnal Manajemen dan Kewirausahaan, Vol.12(1), Hal. 86-97.

Swastha, Basu, D.H, \& Irawan (1990). Manajemen Pemasaran Modern. Liberty, Yogyakarta.

Swastha, B.D.H. 1998. Asas-asas Marketing. Edisi 3. Yogyakarta. Liberty

Tambunan, R. (2001). Remaja dan Pola Hidup Konsumtif dalam http://www.e.psikologi.com. Diakses tanggal 4 November 2016.

Wibowo, Muhammad R. A. (2014). "Analisis Faktor-Faktor Yang Mempengaruhi Keputusan Pembelian Batik Puspa Di Pasar Klewer Surakarta". Skripsi. Universitas Muhammadiyah Surakarta. 